\title{
У THE DEVELOPMENT OF LABIAL CLUSTERS IN THE AŚOKAN ROCK EDICTS
}

\author{
Yasuko Suzuki \\ Kansai Gaidai University
}

\begin{abstract}
The original range of consonant clusters in Indo-Aryan reduced significantly over time, developing into geminates, homorganic nasal-stop clusters, and sonorant- $h$ clusters in Middle Indo-Aryan. Early Middle Indo-Aryan, as represented in the Aśokan inscriptions, however, still maintained the original clusters, or what appear to be transitional stages of the extensive changes. Salient among those cluster changes that are observed in the Aśokan inscriptions are the changes $t m, t v>t p$ and $d v>d b$ in Girnār in the west; $s m, s v>s p$ in Shāhbāzgaṛhī and Mānsehrā in the northwest; and $m h$ $>m b h$ in Kālsī in the north and in Dhaulī and Jaugaḍa in the east. The idiosyncratic nature of these changes lies in the development of a stop from $m$ or $v$, where the more usual changes would be loss or assimilation of $m$ after a stop and of $v$ after a stop or a sibilant, while $s m$ and $h m$ would normally change to $m h$. This paper examines the manner change of the "labial" clusters (that is, the clusters with $m$ or $v$ that normally do not incur assimilation of the adjacent consonant) in the Aśokan Rock Edicts. It discusses the conditions, the motivation, the course of the change of $m / v$ to a labial stop, and the dialectal differences associated with this change.
\end{abstract}

\section{INTRODUCTION}

In Middle Indo-Aryan, consonant clusters underwent extensive changes, including complete assimilation, cluster simplification, vowel epenthesis, sibilant reduction, and metathesis. ${ }^{1}$ These changes reduced the consonant cluster types to geminates, homorganic nasal-stop clusters, and sonorant- $h$ clusters, except for some residues and the clusters that underwent idiosyncratic changes. The assimilation of medial clusters and the simplification of initial clusters have been claimed to be governed by a consonant hierarchy: stops $>$ sibilants/nasals $>l>y>v>r$, in a descending order of strength, whereby a weaker consonant (one that is lower in the hierarchy) is lost when it is adjacent to a stronger consonant (Mehendale 1948: xxiv; von Hinüber 2001: §226; Bubenik 2003: 217-218; Oberlies 2003: 178). Thus, the stronger or the strongest consonant is retained, irrespective of the consonant order in the cluster. For example, nasals, including $m$, assimilate to the preceding stops, and semivowels, including $v$, assimilate to stops and sibilants. The $h$-sonorant and sibilant-nasal clusters become sequences of a sonorant and $h$ by metathesis and, if any, the reduction of a sibilant.

1 This work was supported by JSPS KAKENHI Grant Numbers 17K02702 and 20K00620. I thank two anonymous reviewers for their comments on an earlier version of this paper.

Volume 9(1) (2021), pp. 160-172

DOI 10.23993/store.91999

Licensed under Creative Commons 4.0 (CC BY-NC-SA 4.0) license. 
The term "labial clusters" in the present work refers to the clusters with $m$ or $v$ as the second member, preceded by a stop or a fricative: $t m, t v, d v, s v, s m$, and $h m$. The expression is, therefore, used in a more restrictive sense than it would literally mean. The first four of these clusters are normally affected by perseverative assimilation, according to which the labial nasal or semivowel is lost. The two fricative-nasal clusters are subject to metathesis. That is, the expected developments would be: $t m, t v>t t / t ; d v>d d / d ; s v>s s / s$; and $s m, h m>m h$, if not subject to vowel epenthesis. On the other hand, nasals and $v$ assimilate the adjacent $r$, which is the weakest in the hierarchy. Some Pali examples of perseverative assimilation or loss of $m$ or $v$ are given in (1a), persistence of $m$ or $v$ after $r$ in assimilation in (1b), metathesis of $h$ (including $h$ originating in a sibilant before a nasal) and $m$ or $v$ in (1c), and preservation or reintroduction of the original clusters in (1d) (Pischel 1981: §§277, 287, 300, 313, 315, 330-332, 366a; Sakamoto-Goto 1988; Masica 1991: 171-180; von Hinüber 2001: §§226, 239, 245, 252-253; Suzuki 2002a: 101-103, 106-107, 109-111; 2002b: 81; Oberlies 2003: 172-173, 178-179; 2019: $\S \S 17.4,17.6,19.3,19.4)$. Many of the examples, including atta in (1a) and tvam in (1d), have an alternative form with vowel epenthesis (Pischel 1981: §139; von Hinüber 2001: §155; Oberlies 2019: §17.6). Note that the sibilant-nasal clusters in (1c) show variegated developments; here also epenthesis affects either the original cluster (i.e., sināna) or the metathesized clusters (i.e., nahāna, mihita); in addition, they may be reduced to a sibilant, as in sita.

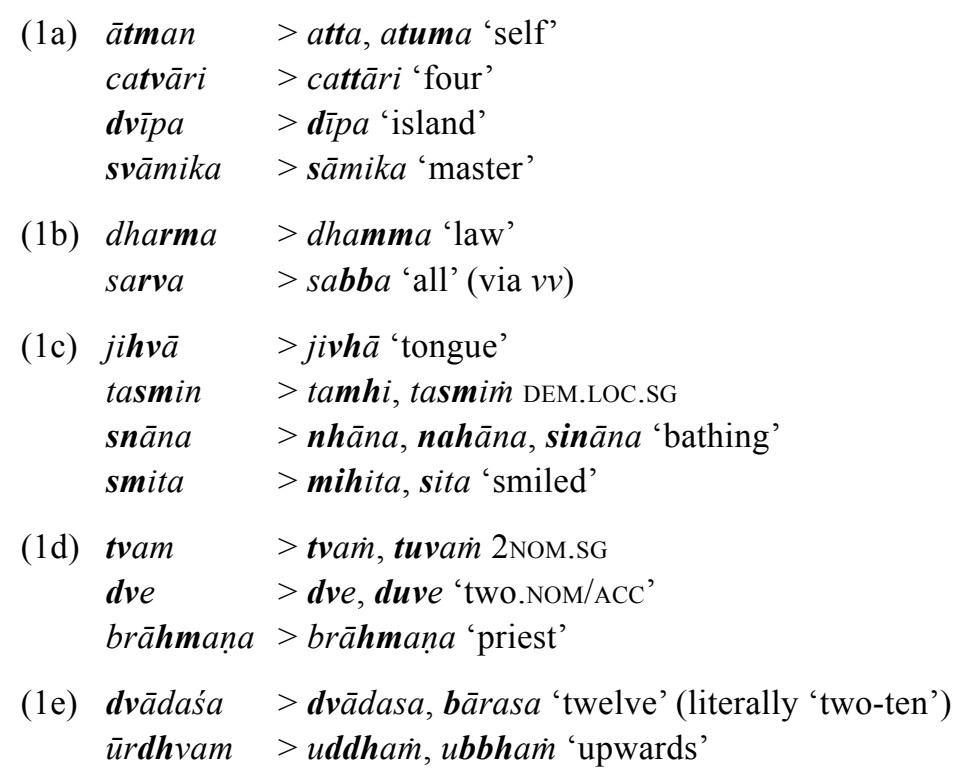

A characteristic example is bārasa in (1e), which has a labial stop as an outcome of $d v$, whereas the expected assimilated outcome would be $d$. In Pali, there are two alternative compound forms for 'two': $d v \bar{a}$ - and $b \bar{a}$ - (Pischel 1981: $\$ 300$; Masica 1991: 172; Norman 1992: 201, 206, 210; 1994b: 28; Geiger 1994: §§53.3, 116.2; von Hinüber 2001: §400; Oberlies 2003: 19;

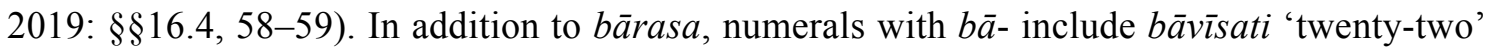
(literally, 'two-twenty') and battimsa 'thirty-two' (literally, 'two-thirty'). While numerals are generally known for idiosyncratic developments, $d v>b$ is, by no means, an isolated case of labial occlusivization. Thus, the assimilated outcome of the tri-consonantal cluster in ürdhvam in (1e) can be the labial stop, as well as the dental stop (von Hinüber 1981 [1994: 168]; 2001: §261; Pischel 1981: §300; Geiger 1994: §59.3). In this case, the outcome results from the coalescence of the manner of $d h$ with the place of $v$. 
The labial articulation of the "weaker" consonant developing into a stop is observed in forms such as Mahārāṣțī appan from Skt. àtman (Mehendale 1948: xxxiii; von Hinüber 1981 [1994: 168]; 2001: §244; Pischel 1981: §277; Sakamoto-Goto 1988: 97, 101, 108 n. 20; Hock 1991a: 63; 1991b: 131; Masica 1991: 179; Norman 1994b: 28); compare the Pali form atta or atuma in (1a). A comparable development of a stop observed in Pali, though not persistence of the "weaker" consonant, is medial $m r$ to $m b$, where the expected outcome would be $\mathrm{mm}$ by assimilation: for example, Skt. tāmra $>$ Pa. tamba 'copper.' Here, the stop $b$ develops out of the transitional phase from the nasal to $r$ by partial denasalization of $m$ (Turner 1960: 30; Pischel 1981: §295; Masica 1991: 175-176; Geiger 1994: §51.5; von Hinüber 2001: §284; Hock 2010: 94-95). The tendency to develop a stop from a non-stop is not restricted to labials. In Pa. Kațthaka (cf. Skt. krṣna) and Vețha- (cf. Skt. viṣnu), the stop develops out of the transitional sound between a sibilant and a nasal (Varma 1929: 123-124; Bloch 1965: 91; Thieme 1992: 14-15; von Hinüber 2001: §285; Oberlies 2001: 180; 2019: §19.5). For similar examples in which a stop develops from a non-stop, see von Hinüber 1981 [1994], Sakamoto-Goto 1988, Thieme 1992, and Hock 2010.

The Aśokan inscriptions represent the earliest attested stage of Middle Indo-Aryan in the third century BCE. The inscriptions show both the residues of inherited clusters and clusters that appear to represent transitional stages in the massive reduction of consonant clusters. Noteworthy among the developments that deviate from the generalization just given is a tendency toward the occlusivization of $m$ and $v$ in prevocalic position: $t m, t v>t p ; d v>d b ; s m, s v>s p$ or $p h ; h m>$ $m b h$. The present work focuses specifically on the Rock Edicts, where dialectal differences are relatively straightforward compared to the rest of the Aśokan inscriptions (Norman 1984-1985 [1990-2007: 126-127]; 1994a: 55; 1994b: 29). It examines the developments of labial clusters in the six dialects of the Aśokan Rock Edicts: Girnār in the west, Shāhbāzgaṛhī and Mānsehrā in the northwest, Kālsī in the north, and Dhaulī and Jaugaḍa in the east. These six dialects are divided into the western group (Girnār, Shāhbāzgaṛhī, and Mānsehrā), which retains the distinction between $l$ and $r$ and tends to preserve consonant clusters, and the eastern group (Kālsī, Dhaulī, and Jaugaḍa), with merger of $r$ to $l$ and fewer consonant clusters. Although the quantity of the examined texts and the vocabulary therein are limited, the evidence of partial assimilation in manner testifies to how the seemingly uniform assimilation of Middle IndoAryan actually developed.

The present work does not subsume the Rock Edicts of Sopārā, Erragudịi, and Sannati. These three are written in the official language of the east, which does not apparently reflect the local dialect of Sopārā in the west and Errraguḍi and Sannati in the south, the latter two of which are in a Dravidian-speaking territory (Norman 1994a: 52-55). The eastern dialect is otherwise represented by the edicts of Dhauli and Jaugaḍa, so adding some more does not affect the given generalizations. For the same reason, the Separate Edicts and the Pillar Edicts, which are in the official language of the east, and the Minor Rock Edicts, which lack the versions of the dialects of the west and the northwest, are not thoroughly examined. These edicts are mentioned only where helpful or necessary.

The transliterated forms of the Rock Edicts, the Separate Edicts, and the Pillar Edicts are cited from Hultzsch (1925: 183-227). Those of the Minor Rock Edicts are cited from Anderson (1990: 112-122). In the original writing, geminates are generally not marked. Thus, for example, ata 'self' and sava 'all' most probably represent atta and savva, respectively. A coda nasal is almost always indicated as anusvāra before any consonant, such as dhamma 
'morality' and bambhana 'priest,' instead of dhamma and bambhana. According to some scholars, anusvāra is occasionally omitted though actually pronounced (Hultzsch 1925: 1x; Mehendale 1948: 25). In the Kharoșthī inscriptions from Mānsehrā and Shāhbāzgaṛhī, vowel length is not marked; thus, for example, bamana 'priest' represents bämaṇa or bammana, along with some other possibilities. In the Brahmī scripts of Girnār, some of the consonant orders have been claimed to be reversed in writing. One example relevant to the following discussion is $p t$, which requires metathesis, for $t p$, which reflects the original order of the consonants tm or $t v$ (Pischel 1881: 1317-1318; Hultzsch 1925: 1viii; Mookerji 1962: 246; Norman 1987 [1990-2007: 275, 278-279, 281]; 1990 [1990-2007: 133-134 fn. 5]; Sakamoto-Goto 1988: 102-104; von Hinüber 2001: §252; 2012: 198-199; Levman 2010: 70); see examples in (2) and (8) below. Hultzsch (1925) transliterates the consonant sequence as $t p$, while Andersen (1990) observes the written consonant order $p t$ in his transliteration of the Minor Rock Edicts. In the present work, the relevant consonant sequence is uniformly written as $t p$ without metathesis. The discussions, however, focus on the shift in manner (i.e., occlusivization) and do not heavily hinge on the consonant order because metathesis, or the lack thereof, is a separate issue. For von Hinüber's (2001) interpretation of the ligature $p t$, see Section 2 below.

Sections 2 and 3 examine the developments of $\mathrm{Cm}$ clusters ( $\mathrm{tm}$, sm, and $\mathrm{hm}$ ) and $\mathrm{Cv}$ clusters ( $t v, d v$, and $s v$ ), respectively, in the Aśokan Rock Edicts. Section 4 provides conclusions.

\section{CLUSTERS WITH M AS THE SECOND MEMBER}

In the vocabulary of the Rock Edicts, there are three clusters with $m$ as the second member where $m$ may develop into a labial stop: $t m, s m$, and $h m$. Of these three, the original cluster tm occurs in one word, ätman 'self, soul,' which shows three-way development, as in (2a): into $t p$ in Girnār; $t$ in Shāhbāzgaṛhī and Kālsī, which may be a geminate as with Pali given in (1a) above; and either $t v$ or $t$ in Mānsehrā (Mehendale 1942: §54; 1948: 26; Bloch 1950: §15; 1965: 85, 87-88; Ghatage 1962: 115-117; Sakamoto-Goto 1988: 96-97; Thieme 1992: 14; von Hinüber 1981 [1994: 167]; 2001: §§244, 252; Hock 1991b: 131; Oberlies 2003: 179; Levman 2010: 70-71, 74). The word does not occur in Dhaulī or Jaugaḍa, which lack Edicts XI to XIII, but the change seen in Girnār from $t m$ to $t p$ is also observed in the Minor Rock Edicts in several places (Hultzsch 1925: cxxv; Bloch 1950: 57; Andersen 1990: 135-136, 162-163). In (2b), occlusivization of $m$ (or possibly $v$ ) is observed in various versions of the Minor Rock Edicts; note that, in Pāngurāriā, the cluster is simplified into a labial stop. In contrast, the last set of examples in (2b) shows simplification into $t$, as in Shāhbāzgaṛhī and Kālsī.

(2a) Skt. ātman > 'self'

RE 12D G. àtpa-, Sh. ata-, M. ata-, K. ata-;

RE $12 \mathrm{H}$ G. ätpa-, Sh. ata-, M. atva-, K. ata-

(2b) Skt. mahātman, mahat-tvā- > MRE 1H 'great.INs.sG'

Br. mahātpen-, Ud. mahatpen-, Eṛ. mahatpen-, Ra. mahatp[e]n-, Pn. mahāpakān-,

Bh. mahatven-, Bi. [ma]hat [ve]n-, Ah. - - tv.n.

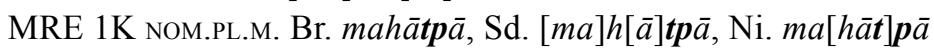

Skt. mahātmatva > MRE 1H 'great.ABL.SG' Ru. mahatatā, Sa. mahatatā

Concerning the interpretation of the orthographic $p t$ (written $t p$ in (2) above and (8) below), von Hinüber (2001: §252; 2012: 198-199) proposes that $p$ represents labialization and not an independent segment; thus, the ligature must be read $t^{v}$. As von Hinüber points out, only three 
of the clusters (other than clusters involving $r$ ), namely, $y v$ and $t s$ in addition to $p t$, have been claimed to be written in the opposite order in Girnār (von Hinüber 2012: 198); the written order thus reflects differences in pronunciation rather than just a haphazard writing. He also observes that $\bar{a} t p \bar{a}$ - or, as is written, $\bar{a} p t \bar{a}$-violates the law of two morae, thus claiming that the intervocalic sounds must represent one single consonant, rather than a consonant cluster (von Hinüber 2012: 199). While the consonant order of the ligature $p t$ has been controversial, von Hinüber's solution also arouses questions, which, in the absence of unequivocal evidence, cannot be answered definitely. The first question again concerns the consonant order: why is the secondary articulation (or diacritical writing, in von Hinüber's term) placed before the major articulation $t$, instead of after $t$ ? Concerning the ligature $t s$, von Hinüber appears to assume that the second consonant represents the secondary articulation, but for $p t$, the first is secondary. Thus, the consonant order lacks consistency in his interpretation as well. The second question concerns the law of two morae, whose strict observance is presupposed by von Hinüber's interpretation. However, this assumption requires justification. Other than several counterexamples given by Sakamoto-Goto (1988: 109 n. 24), which require interpretation of orthography and syllabification, there are a number of forms, such as rāño 'king.GEN.SG' $4 \mathrm{~F}(<$ rājño) and asamāt $[a] \dot{m}$ 'incompletely' 14E (< asamāptam), in which the intervocalic consonants following a long vowel may represent geminates in violation of the law; Bloch (1950: 100, 134) gives a geminate for both, that is, rāñño and asamāttam, respectively. Given that the reduction of the number of morae interacts with and occurs simultaneously with the reduction of consonant clusters, a strict observance of the law of two morae is not to be expected in the western dialects, where a number of consonant clusters remain intact. Thirdly, and most importantly for the present concern, why should the secondary articulation be written as $p$ rather than $v$ (Sakamoto-Goto 1988: 104)? A straightforward interpretation of the orthography would be that some occlusivization is involved.

The second original cluster with prevocalic $m$ - that is, $s m$-occurs in the locative singular suffix of the originally pronominal declension -smin. This cluster consistently becomes $m h$ (which is the regular development in Middle Indo-Aryan; see (1c) above) in Girnār, varies between $s p$ and $s$ in Shāhbazgarhī and Mānsehrā, and is consistently simplified into $s$ in the three eastern dialects, as in (3) (Hultzsch 1925: 1xii, lxiv-lxv, xc; Mehendale 1942: §54; 1948: 26, 28, 38; Bloch 1950: §14; 1965: 90-91; Sakamoto-Goto 1988: 97-99; von Hinüber 2001: §306; Hock 2010: 97; Levman 2010: 74). In the first set of examples in (3), the vowel sandhi is undone because the preceding form is irrelevant for discussions (for example, G. -āgāramhi 6D 'room.LOC.SG' from gabhāgāramhi 6D 'bed-chamber'). In the third set of examples, note that the anusvāra in G. pravāsammhi 9B indicates that $m$ is lengthened (Hultzsch 1925: 1xii).

(3) Skt. āgāra > RE 6D 'room.LOC.SG'

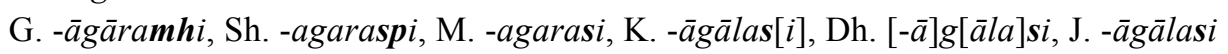

Skt. vinīta $>$ RE 6D 'carriage.Loc.SG'

G. vinitamhi, Sh. vinitaspi, M. vinitaspi, K. vin[itasi], Dh. [v]inītasi, J. vinītas[i]

Skt. pravāsa $>$ RE 9B 'starting on a journey.LOC.SG'

G. pravāsammhi, Sh. pravase, M. pravasaspi, K. pavāsasi, Dh. pavās $[a] s i$,

J. pavāsasi

Skt. $\operatorname{tasmin}>$ RE 12D 'that.LOC.SG'

G. tamhi, Sh. tasi, M. tasi, K. taśi 
In addition, there is one occurrence in Kālsī of an ablative singular form of the demonstrative, with $p h$ in place of the original $s m$, given in (4a) (Mehendale 1948: 26, 28; Bloch 1965: 90-91; Sakamoto-Goto 1988: 100; Hock 2010: 97). While the other dialects lack corresponding forms in the Rock Edicts, the Separate Edicts contain some ablative singular forms of the indefinite pronoun with $s m$, as in the second example in (4a). The Separate Edicts and the Minor Rock Edicts also have several first and second person pronouns, with $p h$ in place of the original $\mathrm{sm}$ (or șm), as in (4b) and (4c), respectively (Hultzsch 1925: cxviii, cxxvii; Varma 1929: 124; Mehendale 1942: §54; 1948: 26, 34; Bloch 1950: 71; Sakamoto-Goto 1988: 98-99; Andersen 1990: 118-122, 152; Thieme 1992: 14; von Hinüber 2001: $\S \S 244,369,371$; Oberlies 2003: 179; Hock 2010: 96-98; Levman 2010: 70). The second person plural pronoun is a blending of the singular $t u$-/tv- and plural $-s m->-p h$-. Thus, the cluster $s m$ shows three-way development in the eastern dialects: $s$ in the locative singular suffix, as in (3); $p h$ in the demonstrative in Kālsī in (4a) and personal pronouns in Dhaulī and Jaugaḍa in (4b, c); and $s m$ in some indefinite pronouns in Dhauli in (4a). If the Edicts reflect the local dialects, which, itself, requires justification, the change sibilant $m>p h$ in pronominal forms appears to be an eastern property.

(4a) Skt. tasmāt $>$ RE 13B DEM.ABL.SG K. [ta]phā

Skt. akasmāt $>\mathrm{SE} 1 \mathrm{~K}$ 'without any cause (< INDF.ABL.SG)' Dh. akasm $\bar{a}$

(4b) Skt. asmāsu > SE 2G J. aphesū 1LOC.PL

Skt. asmākam > SE 2I Dh. aphāka 1DAT.PL

SE 2I Dh. aphe 1ACC.PL cf. Skt. asmān

(4c) SE 1D J. tuphesu 2LOC.PL, Dh. tuphe 2NOM.PL

MRE 1R Ru. tupaka 2GEN.PL; 2T Ud. tuphe, Eṛ. tumphe 2NOM.PL

cf. Skt. tubhyam 2DAT.SG, yușmāsu 2LOC.PL

The third cluster that yields a labial stop from $m$ is the original $h m$, which occurs in the outcomes of Skt. brähmana. This cluster develops into $m h$ by metathesis in Girnār, $m$ by deaspiration in Shāhbazgaṛhī and Mānsehrā, and either $\dot{m} b h$ or $b h$, the latter of which with lengthening of the preceding vowel, in the eastern dialects, as in (5) (Mehendale 1942: §54; 1948: 26; von Hinüber 2001: $\S 224,242,245,284$; Hock 2010: 94-95; Levman 2010: 86 n. 93). The outcomes $\dot{m} b h$ and $b h$ result from retiming of nasality, labial closure, and aspiration - that is, from aspiration followed by simultaneous labial closure and nasality, to labial closure accompanied by nasality at its beginning (or the entire loss of nasality), followed by aspiration at its release. There is one form, K. bamhmane 13J, which is close to the original cluster $h m$, with a slight retiming of aspiration, if the orthography reflects the actual pronunciation.

(5) Skt. brāhmaṇa $>$ RE 3D 'priest'

G. bāmhana-, Sh. bramana-, M. bra[ma]na-, K. baimbhana-, Dh. baimbhana-,

J. baimbhana-

RE 9G STEM or GEN.PL G. bamhana-, Sh. -bramanana, M. -bramaṇana,

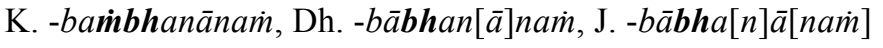

cf. K. baimhmane 13J

A similar development of $b$ from $m$ is observed in the change of $m r>m b$ in the proper name shown in (6) (Mehendale 1942: §55.5.6; 1948: 27). In contrast to the examples given thus far, however, $m$ is the first member of the original cluster. 
(6) tāmra-parṇī > RE 2A 'Tāmraparṇī.NOM.SG'

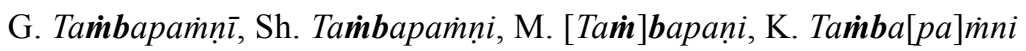

In the last two cases, (5) and (6), the stop arises from partial denasalization of $m: h m>m^{b} h>m b h$, with a shift of aspiration, or $m r>m^{b} r>m b$, with loss of the following $r$. Epenthetic stops of this sort are common cross-linguistically (Browman \& Goldstein 1991: 327; Hock 1991a: 117-119; Ohala 1997; 2003: 681, 682; Warner 2002; Campbell 2013: 31-32; Bybee 2015: 480; Cser 2015: 200; Millar 2015: 61-62). The change from $m r$ to $m b$ occurs in the medial position and shows no variation in the Rock Edicts, where there are only two occurrences, including those in (6). Given that the word is a proper name, the uniformity may result from interdialectal borrowing. Because the change does not involve the prevocalic $m$, this development is not included in Table 1 below.

Note that the change from the labial nasal to the corresponding stop does not affect all clusters involving $m$. Thus, the original cluster $r m$ remains intact (though with metathesis) or is assimilated; compare (7) with (1b) above.

(7) Skt. dharma > RE 4H 'morality'

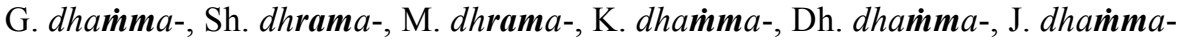

Table 1 summarizes the developments of the three $m$-final clusters in the six dialects of the Rock Edicts. In the rightmost column, ' $\mathrm{C}$ ' and ' $\mathrm{CP} / \mathrm{P}$ ' represent, respectively, an assimilated outcome with loss of $m$ and an outcome whereby $m$ is denasalized with the preceding consonant either retained (CP) or lost (P). Here, 'P' represents a stop outcome of $m$, irrespective of voice and aspiration. The voice of the stop that develops from $m$ is determined by the first consonant of the input: voiceless if the preceding consonant is voiceless, that is $t$ or $s$, but voiced if it is voiced, that is $h$. Aspiration also follows from the input cluster, only occurring when the input $s$ or $h$ is lost in the output. As with other changes of consonant clusters in Middle Indo-Aryan, aspiration is typically associated with the end of the output clusters. In Table 1, the outcomes with a labial stop or semivowel from $m$ by denasalization are indicated in bold in the cells that show results for each dialect, but not in the 'Total' row and column. The unique outcome of $\dot{m} h m$ in Kālsĩ is categorized under ' $m h$,' where aspiration and the nasal stop are reorganized.

Table 1 The development of $t m, s m$, and $h m$ in the six dialects of the Rock Edicts

\begin{tabular}{|c|c|c|c|c|}
\hline Input clusters & $\mathrm{tm}$ & $s m$ & $h m$ & Total \\
\hline Girnār & $\operatorname{tp} 8$ & $m h 26$ & $m h 7$ & $\mathrm{CP} 8, m h 33$ \\
\hline Shāhbāzgaṛhī & $t 8$ & sp $11, s 7$ & $m 8$ & C $15, \mathrm{CP} 11, m 8$ \\
\hline Mānsehrā & $t v 6, t 2$ & sp 4, s 20 & $m 8$ & $\mathrm{C} 22, \mathrm{CP} / t v 10, m 8$ \\
\hline Kālsī & $t 8$ & $s 31$, ph 1 & $\dot{m} h m 1,(\dot{\boldsymbol{m}}) \boldsymbol{b} \boldsymbol{h} 8$ & $\mathrm{C} 39, \mathrm{CP} / \mathrm{P} 9, m h 1$ \\
\hline Dhaulī & & $s 17$ & $(\dot{m}) b h 6$ & $\mathrm{C} 17, \mathrm{CP} / \mathrm{P} 6$ \\
\hline Jaugaḍa & & $s 13$ & $(\dot{\boldsymbol{m}}) \boldsymbol{b h} 2$ & $\mathrm{C} 13, \mathrm{CP} / \mathrm{P} 2$ \\
\hline Total & $t p 8, t v 6, t 18$ & $s p / p h 16, s 88, m h 26$ & $m b h / b h 16, m h / m 24$ & $\mathrm{C} 106, \mathrm{CP} / \mathrm{P} / t v 46, m h / m 50$ \\
\hline
\end{tabular}

As the table shows, the changes from $m$ to a labial stop are nearly complementary in their environments: after $t$ in Girnār (as well as in the Minor Rock Edicts), after $s$ (though not regularly) in Shāhbāzgaṛhī and Mānsehrā, and after $h$ in the three eastern dialects. An alternative development is the change from $t m$ to $t v$, observed only in Mānsehrā. Although the table does not include the outcomes of the Separate Edicts, coalescence of $s m$ to $p h$ in pronominal forms 
is observed also in Dhaulī and Jaugaḍa (as well as in the Minor Rock Edicts), while sm in the locative singular ending is simplified to $s$, as indicated in the table. Girnār is unique in its consistent change from $s m$ or $h m$ to $m h$ with metathesis. In other dialects, excluding the cases of denasalization, the labial nasal in $\mathrm{tm}$ and $\mathrm{sm}$ is assimilated to the preceding consonant. In Shāhbāzgaṛhī and Mānsehrā, $h m$ becomes $m$ by deaspiration. In terms of the lexical categories, the clusters $\mathrm{tm}$ and $\mathrm{hm}$ each occur in one content word in the Rock Edicts- the outcomes of ätman and brähmana, respectively. The cluster sm occurs only in grammatical morphemesthe locative singular suffix and the ablative singular suffix in the Rock Edicts, and, in addition, the first and second personal pronouns in the Separate Edicts and the Minor Rock Edicts. None of the attested outputs of $m$-final clusters are subject to vowel epenthesis.

\section{CLUSTERS WITH V AS THE SECOND MEMBER}

The original clusters with prevocalic $v$, which may develop into a stop, are $t v, d v$, and $s v$ in the vocabulary of the Rock Edicts. The cluster $t v$ occurs several times in the absolutive ending $-t v \bar{a}$, which changes into -tpā in Girnār and -tu in other dialects, as in (8a) (-ti in Mānsehrā derives from -tvī; Hultzsch 1925: 1xix, 1xxii, lxxxiv, lxxxvi, lxxxviii, xcvii, cxi; Mehendale 1942: §47; 1948: 24-25, 45; Bloch 1950: §15; 1965: 87; Ghatage 1962: 115-117; Sakamoto-Goto 1988: 90-91, 93-94; Thieme 1992: 14; von Hinüber 2001: §498). The absolutive ending is consistently -tpa an Girnār, as in ārabhitpā 1B 'slaughter.ABS,' paricajitp $\bar{a} 10 \mathrm{E}$ 'renounce.ABS,' and [a]lochetpa $14 \mathrm{E}$ 'on account of.' Apart from the absolutive, there are three forms with the original -tv-, which develops into $t p$ in Girnār, but remains as $t v$ or is reduced to $t$ in other dialects, as in (8b) (Mehendale 1948: 24-25, 39; von Hinüber 1981 [1994: 167]; 2001: §§252, 396; Sakamoto-Goto 1988: 90-91, 93; Levman 2010: 73); see also (2b) for the Minor Rock Edicts.

(8a) Skt. darśayitva $>$ $>$ RE 4B 'show.ABS'

G. dasayitpāa, Sh. draśayitu, M. draśeti (<-tvī), K. dasayitu, Dh. dasayitu, J. drasayitu

(8b) Skt. hitatvāt $>$ RE 6K 'welfare.ABL.SG' G. -hitatpā

Skt. tadātva- > RE 10A 'present time.LOC.SG'

G. tadātpano, Sh. tadatvaye, M. tadatvaye, K. tadatvāye, Dh. tadatvāye, J. tadatvāye

Skt. catvāri > RE 13Q 'four' G. catpāro, Sh. cature, K. catāli

The original cluster $d v$ occurs in the numeral $d v a$ - 'two' in the Rock Edicts, as in (9). In Girnār, both $d v$ and $d b$, with occlusivization, are observed, while, in Shāhbazgaṛhī, the cluster is simplified to $b$ instead of the expected $d$ in 'twelve' (Hultzsch 1925: lxxiv, lxxxviii, cii; Mehendale 1942: §35; 1948: 24; Ghatage 1962: 115-117; Bloch 1950: §15; 1965: 87; Sakamoto-Goto 1988: 90-93; von Hinüber 2001: $\S \S 253,392,400$; Levman 2010: 72). Otherwise, the cluster is split by an epenthetic vowel. The expected outcome of cluster simplification $d$ is not attested in the Rock Edicts.

(9) Skt. dve > RE 1G 'two' G. dvo, Sh. duv[i], M. du[v]e, K. duve, J. duve

Skt. dvādasa $>$ RE 4K 'twelve'

G. dbādasa-, Sh. badaya-, M. duva[da]śa-, K. duv[ā]das $[a]-$, Dh. duvādasa-

The original cluster $s v$ becomes $s p$ in Shāhbazgaṛhī and Mānsehrā and remains unchanged or is affected by vowel epenthesis in other dialects, as in (10) (Hultzsch 1925: lxxiv, cii; Mehendale 1942: §39; 1948: 25; Bloch 1950: §14; 1965: 90-91; Sakamoto-Goto 1988: 95-96; Levman 2010: 70). 
(10) Skt. svaș̣nām > RE 5M 'sister.GEN.PL' Sh. spasana, M. spas [u]na

Skt. svargam > RE 6L 'heaven.ACC.SG'

G. svagaim, Sh. spagram, M. spagra, K. svagam, Dh. svag[am], Dh. svagam

Skt. svāmikena > RE 9H 'master.INS.SG'

G. svāmikena, Sh. spamik[e]na, M. spamikena, K. suvāmiken[a], Dh. suvāmike[na],

J. suvāmike[na]

The semivowel $v$ is occlusivized only after a stop or a sibilant and, thus, not after $r$, which remains unchanged (with or without metathesis) or is assimilated to the following $v$ (Mehendale 1942: §49; 1948: 25); compare (11) with (1b) above.

(11) Skt. sarva > RE 6F 'all.ACC.SG'

G. sarve, Sh. savam, M. savra, K. savam, Dh. savam, J. savam

Table 2 summarizes the developments of the three $v$-final clusters in the six dialects of the Rock Edicts. 'S' and ' $\mathrm{V}$ ' in the Kālsī row stand for a sibilant of any place and a vowel, either $u$ or $a$, respectively. The outcomes with a labial stop from $v$ are again indicated in bold in the cells that show the results for each dialect. As with $m$, the change from $v$ to a labial stop is conditioned by the same preceding consonant, depending on the dialects: after a stop in Girnār, after $s$ in Shāhbāzgaṛhī and Mānsehrā, and, in part, after $d$ in Shāhbāzgaṛhī; however, occlusivization does not occur in the three eastern dialects. The voice of the output stop agrees with the preceding consonant: voiceless after $t$ or $s$ and voiced after $d$. Otherwise, $t v$ tends to be assimilated; $d v$ is subject to vowel epenthesis; and $s v$ is either preserved or is split by an epenthetic vowel. The contrast between assimilation of the original $t v$ and vowel epenthesis of the original $d v$ and $s v$ may be attributed to the differences in their positions, initial or non-initial, and to the lexical categories in which the clusters occur. More specifically, the original cluster $t v$ occurs in the absolutive suffix $-t v \bar{a}$ and in the nominal suffix $-t v a$, both grammatical morphemes, as well as in one lexical word, catvāri 'four.' Of these three morphemes, in dialects other than Girnār, the cluster in -tva remains unchanged, but, in $-t v \bar{a}$ and catva $r i, v$ is lost by assimilation. All the instances of $t v$ occur in the medial position. By contrast, the original clusters $d v$ and $s v$ occur initially in content words: dve 'two,' svasr 'sister,' svarga 'heaven,' and svämika 'master.' The initial and non-initial positions are often noted as the prominent and non-prominent positions, or as the loci for fortition and lenition, respectively. In the contrastive developments of the $v$-final clusters, the initial cluster in content words tends to be preserved by partial assimilation or vowel epenthesis, while medial clusters, which are less prominent, are more often simplified by assimilation than preserved, except in Girnār.

Table 2 The development of $t v, d v$, and $s v$ in the six dialects of the Rock Edicts

\begin{tabular}{|c|c|c|c|c|}
\hline Input clusters & $t v$ & $d v$ & $s v$ & Total \\
\hline Girnār & $\operatorname{tp} 7$ & $d v 2, \boldsymbol{d} \boldsymbol{b} 2$ & $s v 5$ & $\mathrm{C} v 7, \mathrm{CP} 9$ \\
\hline Shāhbāzgaṛhī & $t v 1, t 7$ & $\boldsymbol{b} 2, d u v 2$ & sp 5 & $\mathrm{C} v 1, \mathrm{C} 7, \mathrm{CP} / \mathrm{P} 7, \mathrm{CV} v 2$ \\
\hline Mānsehrā & $t v 1, t 5$ & $d u v 4$ & sp 4 & $\mathrm{C} v 1, \mathrm{C} 5, \mathrm{CP} 4, \mathrm{CV} v 4$ \\
\hline Kālsī & $t v 1, t 7$ & $d u v 4$ & $s v 1, \mathrm{SV} v 2$ & $\mathrm{C} v 2, \mathrm{C} 7, \mathrm{CV} v 6$ \\
\hline Dhaulī & $t v 1, t 4$ & $d u v 2$ & sv 1, suv 1 & $\mathrm{C} v 2, \mathrm{C} 4, \mathrm{CV} v 3$ \\
\hline Jaugaḍa & $t v 1, t 3$ & $d u v 2$ & sv 3, suv 1 & $\mathrm{C} v 4, \mathrm{C} 3, \mathrm{CV} v 3$ \\
\hline Total & $t v 5, t p 7, t 26$ & $d v 2, d b / b 4, d u v 14$ & $s v 10, s p 9, \mathrm{CV} v 4$ & $\mathrm{C} v 17, \mathrm{C} 26, \mathrm{CP} / \mathrm{P} 20, \mathrm{CV} v 18$ \\
\hline
\end{tabular}




\section{CONCLUSIONS}

The preceding two sections have presented examples in the Rock Edicts and other Aśokan inscriptions of the prevocalic $m$ or $v$ developing into a labial stop after a stop or a fricative. In the cases of $t m, s m, t v, d v$, and $s v$, the change of $m$ or $v$ to a stop involves manner and, where relevant, voice assimilation to the preceding consonant, while, in the change from $\mathrm{hm}$ to $\mathrm{mbh}$ (and also from $\mathrm{mr}$ to $m b$ ), the stop arises as a transitional sound by the partial denasalization of $m$. The development of the labial stop is conditioned by the preceding consonant, which shows near complementarity in regional tendencies. That is, occlusivization is observed consistently after a stop in Girnār ( $\mathrm{tm}$, $t v>t p ; d v>d b)$ and partly in Shāhbāzgaṛhī $(d v>b)$. It occurs typically, though not always, after a sibilant in Shāhbāzgaṛhī and Mānsehrā $(s m, s v>s p)$. However, in the output of $h m, m$ remains a nasal in these three western dialects. In the eastern dialects, on the other hand, an aspirated voiced labial stop arises from $\mathrm{hm}$. In addition, the original cluster $\mathrm{sm}$ is coalesced into $\mathrm{ph}$ in pronominal forms, especially in the first and second personal pronouns in the Separate Edicts in addition to the Minor Rock Edicts, while the comparable pronominal forms are not attested in the western dialects. As has been shown, which clusters yield a stop outcome depends on the dialect in question. The three types of changes that occur in the different dialect groups all result in the same stop outcome but must have occurred independently. A shared tendency is to develop stops from non-stops in prevocalic position, which is the onset and, therefore, prominent. This tendency is also observed in the change from $m r$ to $m b$.

Regarding the change of the prevocalic $m$, previous studies, including Sakamoto-Goto 1988 and von Hinüber 2001: §244, posit the transitional stage of $v: t m>* t v>t p$ and $s m>*_{s v}>s$ or $s p$ (also Ghatage 1962: 118; Thieme 1992; Hock 2010; Oberlies 2019: §17.6). The outcome $t v$ from $t m$ is not only attested in Mānsehrā but also supported by the change $m>v$ in Middle Indo-Aryan in general (Pischel 1981: §251; von Hinüber 2001: §210; Levman 2010: 70). Moreover, both $m$ and $v$ turn into a stop in the same environments in the same dialects. Thus, the intermediate stage of $* t v(<\mathrm{tm})$ or $*_{s v}(<\mathrm{sm})$ reduces the occlusivization of $m$ and $v$ into a uniform process. In addition, the change from $s m$ to $s$ in the three eastern dialects, and partly in Mānsehrā and Shāhbāzgaṛhī, can be considered to conform to the normal process of Middle Indo-Aryan assimilation. That is, while $s m$ turns into $m h$ as a rule, which is the regular outcome in Girnār, the intermediate stage of $*_{s v}(<s m)$ leads naturally to $s$ by assimilation in the other dialects, whereby semivowels are assimilated to sibilants.

On the other hand, the direct change of $m$ to $p$ after a voiceless obstruent, which involves assimilatory denasalization and devoicing, is in no way less natural than assimilatory occlusivization of $v$ to $p$ in the same environment. In fact, there is an example in the Pillar Edicts where intervocalic $m$ becomes a stop with (or due to) a shift of aspiration: PE 5B kaphata- 'tortoise' $<$ kamatha- (Hultzsch 1925: cxiii). At the same time, the outcome $t v$ from tm in Mānsehrā does support the intermediate stage but does not develop into $t p$, failing to provide direct evidence for the posited course of the change: $t m>* t v>t p$. The assimilation of $s m$ to $s$ may follow naturally from the perceptual prominence of the sibilant articulation without the intermediate stage of *sv. Alternatively, in the hierarchy-based analysis, it can be attributed to the vacillating strength relationship between nasals and sibilants. In fact, Pischel (1981: §313) lists both sibilant and nasal outcomes of the locative singular suffix -smin in Middle Indo-Aryan-tassim or taśśim as opposed to tammi-depending on the dialect, which leaves assimilation in both directions possible. Thus, while $s m>s$ may better be mediated through $* s v$, the analysis with 
the intermediate stage of $* v$ in the change $m>p$ does not seem to be justified in every respect (Hock 2010: 97).

The question also arises as to whether the changes of $d v>b$ in Shāhbāzgaṛhī and $s m>p h$ in the eastern dialects are simple coalescence, or if they result from perseverative assimilation followed by loss of the first consonant, as in $d v>* d b>b$ and $s m>*_{s p}>p h$. The stop cluster $d b(<d v)$ attested in Girnār does not necessarily guarantee that the output $b$ in Shāhbāzgaṛhī derives from $d v$ through $* d b$. Similarly, $s p$ from $s m$ in Shāhbāzgaṛhī and Mānsehrā does not necessarily imply that $p h$ develops via $*_{s p}$ from $s m$ in the eastern dialects. That is, given the latitude of dialectal variations, the intermediate stages discussed here lack sufficient support.

Characteristic of the changes discussed in this paper is an inclination toward stops in different ways in different dialects. Stops contrast most strongly with vowels in their phonetic properties and are the unmarked consonants cross-linguistically in terms of their manner of articulation (Maddieson 1984: 25). Functionally, the tendency to develop stops in the prevocalic onset position is motivated by the polarization or enhancement of phonetic difference to vowels for auditory salience (Hock 1991a: 75). Another tendency toward the unmarked structure can be identified in the changes $h m>m b h$ and $m r>m b$, whose outcomes are homorganic nasal-stop clusters, which are cross-linguistically unmarked and common. Other than a propensity toward oral stops or oral closure, tendencies toward a preferred position for certain gestures can be identified in changes of different types, including nasality in coda and aspiration at the release of the cluster, in addition to the tendency to preserve properties of input clusters in simplification of consonant clusters, in the present concern, labial articulation. Why only labials are involved in the Aśokan Rock Edicts may follow from the gaps in consonant clusters. Other input clusters that may develop stops from non-stops are $g n$ and $s n$, both of which occur only once in the Rock Edicts. The medial $g n$ becomes a stop by perseverative assimilation: Skt. agni $>$ 4B 'fire' G. agi-, M. agi-, Dh. [a]gi-, K. agi-. On the other hand, the initial sn undergoes vowel epenthesis in Kālsī and Mānsehrā, though its development is unclear in Shāhbāzgaṛhī: Skt. sneha >13H 'affection. NOM.sG’ K. șinehe, Sh. [si]ho, M. si[ne]he (Lüders 1954: §186; von Hinüber 2001: §153).

While complete assimilation and cluster simplification in Middle Indo-Aryan appear to be governed by a uniform principle, the variegated developments of labial clusters in the Rock Edicts are a testament to the several independent, but interacting, principles involved-most notably occlusivization.

$\begin{array}{llll}\text { ABBREVIATIONS } & & \\ 1 & \text { First person } & \text { INDF } & \text { Indefinite } \\ 2 & \text { Second person } & \text { INS } & \text { Instrumental } \\ \text { ABL } & \text { Ablative } & \text { LOC } & \text { Locative } \\ \text { ABS } & \text { Absolutive } & \text { M } & \text { Masculine } \\ \text { ACC } & \text { Accusative } & \text { NOM } & \text { Nominative } \\ \text { DAT } & \text { Dative } & \text { PL } & \text { Plural } \\ \text { DEM } & \text { Demonstrative } & \text { SG } & \text { Singular } \\ \text { GEN } & \text { Genitive } & & \end{array}$




\begin{tabular}{|c|c|c|c|}
\hline Ah. & Ahraurā (Uttar Pradesh) & $\mathrm{Pa}$. & Pali \\
\hline Bh. & Bahāpur (South Delhi) & $\mathrm{PE}$ & Pillar Edicts \\
\hline Bi. & Bairāṭ (Rajasthan) & Pn. & Pānguṛāriā (Madhya Pradesh) \\
\hline $\mathrm{Br}$. & Brahmagiri (Karnataka) & $\mathrm{Ra}$. & Rājula-Maṇḍagiri (Andhra Pradesh) \\
\hline Dh. & Dhaulī (Odisha) & $\mathrm{RE}$ & Rock Edicts \\
\hline Err. & Errraguḍi (Andhra Pradesh) & $\mathrm{Ru}$. & Rūpnāth (Madhya Pradesh) \\
\hline G. & Girnār (Gujarat) & Sa. & Sahasrām (Bihar) \\
\hline J. & Jaugaḍa (Odisha) & SE & Separate Edicts \\
\hline K. & Kālsī (Uttarakhand) & Sh. & Shāhbāzgaṛhī (Pakistan) \\
\hline M. & Mānsehrā (Pakistan) & $\mathrm{Sd}$. & Śiddāpura (Karnataka) \\
\hline MRE & Minor Rock Edicts & Skt. & Sanskrit \\
\hline Ni. & Nitṭūr (Karnataka) & Ud. & Uḍegoḷam (Karnataka) \\
\hline
\end{tabular}

\section{REFERENCES}

Andersen, Paul Kent 1990. Studies in the Minor Rock Edicts of Aśoka, I: Critical Edition. Freiburg: Hedwig Falk. BLoch, Jules 1950. Les inscriptions d'Asoka. Paris: Les Belles Lettres.

BLoch, Jules 1965. Indo-Aryan from the Vedas to Modern Times. English edition, largely revised by the author and translated by Alfred Master. [Revision and translation of L'ndo-aryen du véda aux temps moderne. 1934.] Paris: Adrien-Maisonneuve.

Browman, Catherine \& Louis Goldstern 1991. Gestural Structures: Distinctiveness, Phonological Processes, and Historical Change. In: I.G. Mattingly \& M. Studdert-Kennedy (eds), Modularity and the Motor Theory of Speech Perception: 313-338. Hillsdale, NJ: Lawrence Erlbaum.

Bubenik, Vit 2003. Prākrits and Apabramiśa. In: G. CARdona \& D. Jain (eds): 204-249.

Bybee, Joan 2015. Articulatory Processing and Frequency of Use in Sound Change. In: P. Honeybone \& J. Salmons (eds): 467-484.

CAmpbell, Lyle 2013. Historical Linguistics: An Introduction. 3rd edn. Edinburgh: Edinburgh University Press.

CARDona, George \& Dhanesh JAIN (eds) 2003. The Indo-Aryan Languages. London: Routledge.

Cser, András 2015. Major Types of Sound Change. In: P. Honeybone \& J. SAlmons: 198-204.

Geiger, Wilhelm 1994. A Pali Grammar. Tr. Batakrishna Ghosh. Rev. \& ed. K.R. Norman. Oxford: Pali Text Society. Ghatage, A.M. 1962. Historical Linguistics and Indo-Aryan Languages. Bombay: University of Bombay.

von HiNÜBer, Oskar 1981. Die Entwicklung der Lautgruppen -tm-, - $d m$-, und -sm- im Mittel- und Neu-indischen. Münchener Studien zur Sprachwissenschaft 40: 61-71. [English translation 1994. The Development of the Clusters -tm-, -dm-, and -sm- in Middle and New Indo-Aryan. Selected Papers on Pāli Studies: 162-172. Oxford: The Pali Text Society.]

VON HINÜBER, Oskar 2001. Das ältere Mittelindisch im Überblick. 2nd edn. Wien: Verlag der Österreichische Akademie der Wissenschaften.

VON HINÜBER, Oskar 2012. Linguistic Experiments: Language and Identity in Aśokan Inscriptions and in Early Buddhist Texts. In: P. Olivelle, J. LeoshKo \& H.P. Ray (eds), Re-imagining Aśoka: Memory and History: 195-206. New Delhi: OUP. [Reprint 2019. Harry FalK, Haiyan Hu-von Hinüber \& Walter Slaje (eds), Oskar von Hinüber. Kleine Schriften, III: 1347-1358. Wiesbaden: Harrassowitz.]

Hock, Hans Henrich 1991a. Principles of Historical Linguistics. 2nd edn. Berlin: De Gruyter.

Hock, Hans Henrich 1991b. Dialects, Diglossia, and Diachronic Phonology in Early Indo-Aryan. In: W.G. Boltz \& M.C. ShapIro (eds), Studies in the Historical Phonology of Asian Languages: 119-159. Amsterdam: Benjamins.

Hock, Hans Henrich 2010. Middle Indo-Aryan “Aspirate” Clusters Revisited. Studia Orientalia 108: 87-102.

Honeybone, Patrick \& Joseph Salmons (eds) 2015. The Oxford Handbook of Historical Phonology. Oxford: OUP.

Hultzsch, E. 1925. Inscriptions of Aśoka: New Edition. (Corpus Inscriptionum Indicarum I) Oxford: Clarendon Press, for the Government of India. [Reprint 1969. Delhi: Indological Book House.]

Levman, Bryan 2010. Aśokan Phonology and the Language of the Earliest Buddhist Tradition. Canadian Journal of Buddhist Studies 6: 57-86. 
LÜDERS, Heinrich 1954. Beobachtungen über die Sprache des buddhistischen Urkanons. Berlin: Akademie Verlag.

MadDieson, Ian 1984. Patterns of Sounds. Cambridge, UK: CUP.

Masica, Colin P. 1991. The Indo-Aryan Languages. Cambridge, UK: CUP.

Menendale, Madhukar Anant 1942. A Comparative Grammar of Aśokan Inscriptions. Bulletin of the Deccan College Post-Graduate and Research Institute 3: 225-290.

Menendale, Madhukar Anant 1948. Historical Grammar of Inscriptional Prakrits. Poona: Deccan College Postgraduate and Research Institute. [Reprint 1997.]

Millar, Robert McColl (ed.) 2015. Trask's Historical Linguistics. 3rd edn. London: Routledge.

MookerJI, Radhakumud 1962. Asoka. 3rd rev. edn. Delhi: Motilal Banarsidass. [6th reprint 2016.]

Norman, K.R. 1984-1985. A Dialect Variation in Aśoka's Minor Rock Edict I. Journal of Ancient Indian History XV: 1-14. [Reprint NoRman 1990-2007, 3: 126-136.]

Norman, K.R. 1987. The Orthography of the Girnār Version of the Aśokan Rock Edicts. Bulletin d'études indiennes 5: 273-285. [Reprint NoRMAN 1990-2007, 3: 274-282.]

Norman, K.R. 1990. Orthographical Problems in the Aśokan Inscriptions. In: K.V. RameSh, S.P. TeWARI \& M.J. Sharma (eds) Indian History and Epigraphy: Dr. G.S. Gai Felicitation Volume: 100-105. Delhi: Agam Kala Prakashan. [Reprint Norman 1990-2007, 5: 132-143.]

Norman, K.R. 1990-2007. Collected Papers. 8 vols. Oxford: The Pali Text Society. [Reprint 1999-2017. Oxford: The Pali Text Society.]

Norman, K.R. 1992. Middle Indo-Aryan Numerals. In: Jadranka Gvozdanovic (ed.), Indo-European Numerals: 199-241. Berlin: De Gruyter. [Reprint Norman 1990-2007, 5: 1-25.]

Norman, K.R. 1994a. The Aśokan Inscriptions and Prakrit Dialect Geography. In: N.N. Bhattacharyya (ed.), Jainism and Prakrit in Ancient and Medieval India: Essays for Prof. Jagdish Chandra Jain: 51-57. New Delhi: Manohar. [Reprint Norman 1990-2007, 6: 1-8.]

Norman, K.R. 1994b. The Development of the Middle Indo-Aryan Dialects. Memoirs of the Chūo Academic Research Institute 23: 21-50. [Reprint Norman 1990-2007, 6: 88-145.]

OBerLies, Thomas 2001. Pāli: A Grammar of the Language of the Theravāda Tipitaka. Berlin: De Gruyter.

OBerlies, Thomas 2003. Aśokan Prakrit and Pali. In: G. CARdona \& D. Jain: 161-203.

OBerlies, Thomas 2019. Pāli Grammar: The Language of the Canonical Texts of Theravāda Buddhism, I: Phonology and Morphology. Bristol: The Pali Text Society.

Ohala, John J. 1997. Emergent Stops. Proceedings of the 4th Seoul International Conference on Linguistics 11-15 Aug 1997: 84-91.

Ohala, John J. 2003. Phonetics and Historical Phonology. In: B.D. Joseph \& R.D. Janda (eds), Handbook of Historical Linguistics: 669-686. Malden, MA: Blackwell.

Pischel, Richard 1881. Review of É Senart, Les Inscriptions de Piyadasi. Göttingische gelehrte Anzeigen 42: 13131337. [Reprint 2020. Nalini BalbiR \& Georges-Jean Pinault (eds), Richard Pischel: Kleine Schriften: 248-272. Wiesbaden: Harrassowitz.]

Pischel, Richard 1981. A Grammar of the Prakrit Languages. 2nd rev. edn. Tr. from German Subhadra Jha. Delhi: Motilal Banarsidass.

SАкамото-Gото, Junko 1988. Die mittelindische Lautentwicklung von $v$ in Konsonantengruppen mit Verschlußlaut bzw. Zischlaut. Indo-Iranian Journal 31: 87-109.

Suzuki, Yasuko 2002a. Consonant Cluster Changes in Pali, Part I. Journal of Inquiry and Research 75: 97-125.

SuZUKI, Yasuko 2002b. Consonant Cluster Changes in Pali, Part II. Journal of Inquiry and Research 76: 63-86.

THIEME, Paul 1992. Assimilation eines stimmhaften Konsonanten (v, ḍ und g) nach Sibilant oder stimmlosem Verschlußlaut, d. h. Ersetzung durch p, ț und k im Prakrit. Historische Sprachforschung 105: 13-15.

TURner, Ralph Lilley 1960. Some Problems of Sound Change in Indo-Aryan. Poona: University of Poona.

VARMA, Siddheshwar 1929. Critical Studies in the Phonetic Observations of Indian Grammarians. London: Royal Asiatic Society. [Reprint 1961. Delhi: Munshi Ram Manohar Lal.]

Warner, Natasha 2002. The Phonology of Epenthetic Stops: Implications for the Phonetics-Phonology Interface in Optimality Theory. Linguistics 40: 1-27. 